\title{
Therapeutic potential of a designed CSaß peptide ID13 in Staphylococcus aureus-induced endometritis of mice
}

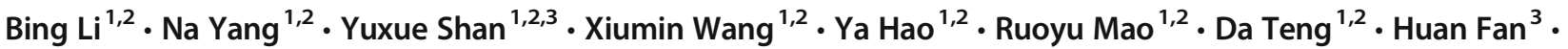 \\ Jianhua Wang ${ }^{1,2}$ (D)
}

Received: 3 April 2020 / Revised: 7 May 2020 / Accepted: 17 May 2020 / Published online: 6 June 2020

(C) Springer-Verlag GmbH Germany, part of Springer Nature 2020

\begin{abstract}
Staphylococcus aureus is a common pathogen that can cause clinical and subclinical endometritis in humans and animals. In this study, a designed CS $\alpha \beta$ peptide ID13 from DLP4 exhibited high stable antibacterial activity in simulated gastric fluid (90.79\%), serum (99.54\%), and different $\mathrm{pH}$ buffers (>99\%) against $S$. aureus CVCC 546 and lower cytotoxicity (89.62\% viability) than its parent peptide DLP4 (74.14\% viability) toward mouse endometrial epithelial cells (MEECs). ID13 caused a depolarization of bacterial membrane and downregulation of the expression of genes involved in membrane potential maintenance and biofilm formation. The in vitro efficacy analysis of ID13 showed a synergistic effect with vancomycin, ampicillin, rifampin, and ciprofloxacin; intracellular antimicrobial activity against $S$. aureus CVCC 546 in MEECs; and the ability to inhibit lipoteichoic acid-induced pro-inflammatory cytokines from RAW 264.7. In the $S$. aureus-induced endometritis of mice, similar to vancomycin, ID13 remarkably alleviated pathological conditions, inhibited the production of cytokines (TNF- $\alpha$, IL-1ß, IL-6, and IL10), and suppressed the TLR2-NF-KB signal pathway. Collectively, these results suggest that ID13 could be a potential candidate peptide for therapeutic application in $S$. aureus-induced endometritis.
\end{abstract}

\section{Key Points}

-Higher antibacterial activity and lower hemolysis of ID13 than DLP4.

-ID13 could downregulate the genes of bacterial survival and infection.

-ID13 could alleviate the $S$. aureus-induced endometritis of mice.

-ID13 could regulate the cytokines and suppress the TLR2-NF- $\kappa B$ signal pathway.

Keywords Therapeutic potential $\cdot \mathrm{CS} \alpha \beta$ peptide $\cdot$ Staphylococcus aureus $\cdot$ Transcriptome sequencing $\cdot$ Endometritis

Bing Li, Na Yang and Yuxue Shan contributed equally to this work.

Electronic supplementary material The online version of this article (https://doi.org/10.1007/s00253-020-10685-x) contains supplementary material, which is available to authorized users.

Ruoyu Mao

maoruoyu@ caas.cn

Da Teng

tengda@caas.cn

$\triangle$ Jianhua Wang

wangjianhua@caas.cn; 2681298635@qq.com

1 Team of Alternatives to Antibiotics, Gene Engineering Lab, Feed Research Institute, Chinese Academy of Agricultural Science, Beijing 100081, People's Republic of China

2 Key Laboratory of Feed Biotechnology, Ministry of Agriculture and Rural Affairs, Beijing 100081, People's Republic of China

3 Tianjin Animal Science and Veterinary Research Institute, Tianjin 300381, People's Republic of China

\section{Introduction}

Staphylococcus aureus is a facultative pathogen that can cause myriad infectious diseases in humans and animals (Fluit 2012; Foster 2012; Lai et al. 2018; Tong et al. 2015), including endometritis, a common reproductive disease (Sheldon and Owens 2017), and severely impaired reproductive performance (Gilbert et al. 2005); if not controlled, it may promote the development of septicemia and sepsis (Skovbakke and Franzyk 2017). It is estimated that 340 million women get bacterial infections in the uteri each year, and 15 20\% animals develop clinical or subclinical endometritis beyond 3 weeks post-partum, costing billion dollars for treatments annually (Turner et al. 2012). In this study, our focus is mainly on breeding animals, such as cows and sows, which are more susceptible to pathogenic infections under intensive cultivation pressure. Antibiotics are widely used in the clinical prevention and treatment of endometritis, which has increased the 
emergence of antibiotic-resistant bacteria, especially multidrug resistant (MDR) bacteria (Eslami et al. 2015). It has been found that $S$. aureus is resistant to tetracycline (43.5\%), penicillin $(81 \%)$, erythromycin $(44.5 \%)$, clindamycin $(51.2 \%)$, and ciprofloxacin (30\%) (Wu et al. 2019). Meanwhile, the traditional screening of new antibacterial has suffered a considerable decline (da Cunha et al. 2017). This not only affects the treatment options but also may endanger public health (Coyne et al. 2019; Coyne et al. 2016). In recent years, antimicrobial peptides (AMPs) have attached attention of scientists by their properties such as broad-spectrum antimicrobial activity and non- or low resistance of bacteria.

Among AMPs, insect defensins (with 32-52 residues) are a large group of evolutionarily conserved cationic, cysteine-rich peptides and display a broad-spectrum activity against bacteria, fungi, and virus. They share a cysteine-stabilized $\alpha \beta$ motif $(\operatorname{CS} \alpha \beta)$, which has been proved to be a valuable structural template for the development of novel antimicrobials (Koehbach 2017). However, natural insect defensins often have low activity and some toxicity toward mammalian cells, which limit their therapeutic application (Barreto-Santamaria et al. 2019). Therefore, some engineered peptides were designed based on the $\mathrm{CS} \alpha \beta$ scaffold, such as tenecin 1, DefAcAA, and NZ2114, and they exhibited improved antibacterial activity and reduced cytotoxicity (Ahn et al. 2006; Landon et al. 2008; Zhang et al. 2014). Although, many attempts have been made on the medical application of AMPs, few of them have been introduced into the market yet (Kang et al. 2017; Yi et al. 2014). The screening and testing of effective AMPs (or designer AMPs) for therapeutic applications are ongoing in the pharmaceutical industry (Andersson et al. 2016).

In our previous study, a designed $\mathrm{CS} \alpha \beta$ peptide ID13 from DLP4 showed enhanced activity (MIC 0.95 1.91 $\mu \mathrm{M}$ ), reduced hemolysis, and cytotoxicity toward mouse macrophages RAW 264.7 ( $\mathrm{Li}$ et al. 2020). In the present study, effects of ID13 on bacterial membrane and gene expression of $S$. aureus CVCC 546 were explored, and its in vitro and in vivo therapeutic efficacies were evaluated through AMPantibiotic synergism, intracellular antimicrobial action, lipoteichoic acid (LTA) neutralization, and mouse endometritis model.

\section{Materials and methods}

\section{Strains, cell lines, and reagents}

The bacterial strains Staphylococcus epidermidis ATCC 12228 and Escherichia coli ATCC 25922 were purchased from American Type Culture Collection (ATCC). S. aureus CVCC 546, Streptococcus pneumoniae CVCC 2350, Streptococcus suis CVCC 3928, Salmonella pullorum CVCC 533, and Salmonella Enteritidis CVCC 3377 were purchased from the China Veterinary Culture Collection Center (CVCC). Mouse macrophages RAW 264.7 and endometrial epithelial cells (MEECs) were obtained from Peking Union Medical College and iCell Bioscience Inc. (Shanghai, China), respectively. LTA and 3-(4, 5-dimethylthiazol-2-yl)2, 5-diphenyltetrazolium bromide (MTT) were purchased from Sigma-Aldrich (China). Antibiotics used in the study were purchased from Meilun Biotech Co., Ltd (Dalian, China). Peptides ID13 and DLP4 were expressed and purified in our lab as previously described ( $\mathrm{Li}$ et al. 2020), with the purity of $91.2 \%$ and $92 \%$, respectively. Other reagents were of analytical grade.

\section{Bioavailability of peptides}

\section{Antimicrobial activity}

The antimicrobial activity of peptides was calculated by minimal inhibitory concentration (MIC) via microtiter plate assay as previously depicted (Wiegand et al. 2008). Each test was conducted in triplicate.

\section{Peptide stability in biological fluids}

The stability of peptide ID13 in simulated gastric fluid (SGF), simulated intestinal fluid (SIF), and mouse serum was carried out as previously described (Benincasa et al. 2010; Liu et al. 2013; Yu et al. 2019). Simply, a final concentration of $100-\mu \mathrm{g} / \mathrm{mL}$ ID13 was prepared with SGF, SIF, or $25 \%$ serum and incubated at $37^{\circ} \mathrm{C}$. At different time intervals, an aliquot of 30- $\mu \mathrm{L}$ ID13 mix was taken and tested against $S$. aureus CVCC 546 by drop diffusion assay (Cerovsky et al. 2011). ID13 $(100 \mu \mathrm{g} / \mathrm{mL})$ prepared with PBS was used as a positive control; SGF, SIF, and $25 \%$ serum were used as negative controls. The agar plates were incubated overnight at $37{ }^{\circ} \mathrm{C}$, and inhibition zones were determined.

\section{Anti-S. aureus activity of ID13 at different pH}

The antimicrobial activity of ID13 $(100 \mu \mathrm{g} / \mathrm{mL})$ in different $\mathrm{pH}$ buffers ( $\mathrm{pH}$ 2.0, 4.0, 6.0, 8.0, and 10.0) was tested $(\mathrm{Yu}$ et al. 2019). After incubated with different $\mathrm{pH}$ buffers at $37^{\circ} \mathrm{C}$ for $3 \mathrm{~h}, 30-\mu \mathrm{L}$ ID13 and corresponding controls were dropped on Mueller-Hinton agar (MHA) plate and incubated overnight at $37^{\circ} \mathrm{C}$ for anti-S. aureus activity determination.

\section{Mammalian cytotoxicity}

The effect of peptides on MEECs' viability was evaluated by using the MTT assay as depicted before (Wang et al. 2018). 


\section{Effects of ID13 on S. aureus membrane and gene expression}

\section{Membrane depolarization}

Membrane depolarization was carried out as depicted previously with some slight modifications (Kindmark et al. 2001; Yang et al. 2019). S. aureus CVCC 546 cells at $10^{8} \mathrm{CFU} / \mathrm{mL}$ were treated with peptides at $1 \times, 2 \times$, or $4 \times \mathrm{MIC}$. After incubation at $37^{\circ} \mathrm{C}$ for $2 \mathrm{~h}$, the bacteria were washed twice with PBS buffer and resuspended. A final concentration of 1- $\mu \mathrm{M}$ Rhodamine 123 (Rh123) was added. The cells without peptide treatment were set as negative control. After incubation at $37{ }^{\circ} \mathrm{C}$ for $30 \mathrm{~min}$, Rh123 fluorescence from the cytoplasm was detected by flow cytometry.

\section{Transcriptome sequencing}

S. aureus CVCC 546 at $2.5 \times 10^{8} \mathrm{CFU} / \mathrm{mL}$ was inoculated into 250-mL Erlenmeyer flasks. The cultures were supplemented with peptide ID13 at subinhibitory concentration (4 $\mu \mathrm{g} / \mathrm{mL}$ ) at $37^{\circ} \mathrm{C}$ for $60 \mathrm{~min}$. RNA extraction was then performed using an RNeasy mini kit (Qiagen). The RNAs from three biological replicates were pooled; library preparation and RNA sequencing (RNA-seq) were conducted in Novogene (Beijing, China). Bioinformatic analysis was carried out using the CLC Genomics Workbench. Primary sequencing reads were mapped to the reference transcriptome and genome of $S$. aureus TW20 (GenBank accession number FN433596). The abundances of transcripts were generated in fragments per kilobase of transcript sequence per million base pairs sequenced (FPKM) (Trapnell et al. 2010). Differential expression analysis was assessed with an $\mathrm{R}$ package, where $\mid \log _{2}$ (fold change) $\mid>1$ and $q$ value $<0.005$ were used as screening criteria for differential genes (Wang et al. 2010). For function and pathway analysis, we used the GOseq software (Young et al. 2010) and KEGG database (http://www. genome.jp/kegg/). The raw sequence data are publicly accessible at https://bigd.big.ac.cn/gsa/browse/CRA002331.

\section{Efficacies of peptide ID13 in vitro}

\section{ID13-antibiotic synergism}

Combinatory interactions of ID13 and antibiotics were tested by using the checkerboard titration method as described previously (Zhang et al. 2014).

\section{Intracellular antimicrobial activity}

$S$. aureus can internalize into host cells to avoid being killed by traditional antibiotics (Wang et al. 2019). To explore the intracellular antimicrobial activity of ID13, MEECs prepared in DMEM free of antibiotics were dispensed in 12-well plates at $2.5 \times 10^{5}$ cells $/ \mathrm{mL}$ and $750 \mu \mathrm{L} /$ well. After $24-\mathrm{h}$ incubation, an equal volume of $S$. aureus CVCC 546 at $2.5 \times 10^{7} \mathrm{CFU} /$ $\mathrm{mL}$ was supplemented and coincubated with MEECs for 0.5 h. Then, $50 \mu \mathrm{g} / \mathrm{mL}$ of lysostaphin was added and incubated for $1 \mathrm{~h}$ to kill extracellular bacteria. After washing with PBS, the MEECs were treated with different concentrations of peptides or vancomycin for $24 \mathrm{~h}$ and processed for colony counting (Di Grazia et al. 2014).

\section{LTA neutralization}

The anti-inflammatory activity of peptide ID13 was analyzed as depicted previously with some modifications (Liu et al. 2013; Skovbakke and Franzyk 2017). The mouse macrophages RAW 264.7 were resuspended in DMEM to a density of $1 \times 10^{6}$ cells $/ \mathrm{mL}$; an aliquot of $500 \mu \mathrm{L} /$ well was seeded in 24-well plates for 24-h incubation. A final concentration of $10-\mu \mathrm{g} / \mathrm{mL}$ LTA was then added and incubated for another $3 \mathrm{~h}$. After washing with PBS, cells were treated with peptides at different concentrations. Cells treated with DLP4 and vancomycin or ones untreated were used as positive and negative controls. The supernatants were harvested and analyzed for cytokine levels of TNF- $\alpha$, IL-1ß, IL-6, and IL-10 using an enzyme-linked immunosorbent assay (ELISA) kit (R\&D systems, USA). Each group was made in triplicate.

\section{Efficacies of peptide ID13 in mice endometritis model}

The animal procedures were approved by the Institutional Animal Care and Use Committee of Chinese Academy of Agricultural Sciences (CAAS). Animal studies were performed with female CD-1 mice, weight $25 \mathrm{~g}$. Sixty mice were randomly divided into six groups $(n=10)$. To induce endometritis, $100-\mu \mathrm{L}$ S. aureus CVCC $546\left(1 \times 10^{8} \mathrm{CFU} / \mathrm{mL}\right)$ was injected into the uteri of mice via vagina for 3 days with a 1-mL syringe. Twenty-four hours post-infection, mice were administered intraperitoneally (i.p.) with peptides at 5, 10, or $15 \mathrm{mg} / \mathrm{kg}$ once daily for 3 days. Mice raised without any treatment, treated with vancomycin, or treated with PBS were used as the blank, positive, and negative controls, respectively. At $24 \mathrm{~h}$ post-treatment, peripheral blood and the uterine tissues were collected from the mice. Peripheral blood $(n=5)$ from the negative and blank control was used for white blood cell analysis; the others $(n=5)$ from each group were centrifuged; and the serum was used for TNF- $\alpha$, IL-1ß, IL-6, and IL-10 analysis by using the ELISA kit (R\&D systems, USA). Uteri $(n=5)$ from each group were homogenized; the homogenate was diluted with a 1: $10(\mathrm{w} / \mathrm{v})$ ratio and dropped on Baird-Parke (BP) agar plate for pathogenic bacteria isolation and identification. Segments from another five uteri in each group were fixed in 4\% paraformaldehyde for histopathological analyses by hematoxylin-eosin (H\&E) staining; the rest 
ones were extracted for TLR2 and NF- $\mathrm{BB}$ pathway analysis by western blot ( $\mathrm{Li}$ et al. 2015).

\section{Statistical analysis}

All data were analyzed with GraphPad Prism 7 and presented as mean \pm standard deviation (SD), where " $n$ " represents the number of animals or samples. Comparisons between groups were performed by one-way analysis of variance (ANOVA) followed by Dunnett's multiple test. $p<0.05$ was considered statistically significant.

\section{Results}

\section{Bioavailability of peptide ID13}

\section{Antimicrobial activity}

As shown in Table 1, the activity of ID13 with MICs of $0.95 \sim 1.91 \mu \mathrm{M}$ was higher than that of its parent peptide DLP4 with MICs of 3.75 14.99 $\mu \mathrm{M}$ against $S$. aureus CVCC 546, S. epidermidis ATCC 12228, S. pneumoniae CVCC 2350, and S. suis CVCC 3928, respectively. However, similar to DLP4, ID13 had no activity against Gram-negative bacteria (MIC > $30.5 \mu \mathrm{M})$.

\section{Stability of peptide ID13 in biological fluids}

Proteases in the gastrointestinal tract and blood limit the use of AMPs (da Cunha et al. 2017; Yu et al. 2019). The susceptibility of peptide ID13 to pepsin, trypsin, and serum was detected by using the drop diffusion method. After treatment with SGF or $25 \%$ serum for $60 \mathrm{~min}$, peptide ID13 retained $90.79 \%$ or $99.54 \%$ activity against $S$. aureus CVCC 546, respectively, while it has easily undergone proteolysis in less than 5 min in SIF (Fig. 1a).

The varying $\mathrm{pH}$ buffers (2.0 to 10.0 ) had no effect on ID13 activity (>99\%) against $S$. aureus CVCC 546 (Fig. 1b). These results indicate that ID13 can be used via oral administration.

\section{Cytotoxicity of peptides toward MEECs}

The cell viability of ID13 toward MEECs was $89.62 \%$ at a concentration of $256 \mu \mathrm{g} / \mathrm{mL}$, which was nearly equal with that of vancomycin (90.15\%), and showed lower cytotoxicity than that of DLP4 $(74.14 \%)$ at $256 \mu \mathrm{g} / \mathrm{mL}$, indicating a low cytotoxicity (Fig. 1c).

\section{Effects of peptide ID13 on S. aureus CVCC 546}

\section{ID13-depolarized S. aureus CVCC 546 membrane}

As shown in Fig. 2a, when $S$. aureus CVCC 546 cells were treated with peptide ID13 at $1 \times, 2 \times$, or $4 \times$ MIC for $2 \mathrm{~h}$, the fluorescence intensity of Rh 123 was reduced by $23.54 \%$, $26.49 \%$, and $23.05 \%$, respectively. There was no significant concentration relationship of ID13. Comparably, the fluorescence intensity from cells treated with $1 \times, 2 \times$, or $4 \times \mathrm{MIC}$ vancomycin was dose-dependently increased by $23.1 \%$, $26.6 \%$, and $32.3 \%$, respectively. The membrane depolarization by ID13 correlates with the findings of the transcriptional analyses as follows.

ID13 regulated S. aureus CVCC 546 gene expression To investigate the effects of ID13 on gene expression of $S$. aureus, transcriptome sequencing was performed. A total of 640 differentially expressed genes (DEGs) were identified, including 266 upregulated genes and 374 downregulated genes (Fig. 2b). Significant changes in response to ID13 are involved in the genes that are essential to metabolic processes and pathways such as membrane function, biosynthesis of primary and secondary metabolites, and microbial metabolism in diverse environments (Fig. 2c-d), which play an important role in cell viability and pathogenicity.

\section{Membrane potential $(\Delta \Psi)$-related genes}

$\Delta \Psi$ is crucial to energy metabolism and is maintained by the transmembrane gradients of ions $\left(\mathrm{Na}^{+}, \mathrm{K}^{+}, \mathrm{Cl}^{-}\right.$, and $\mathrm{H}^{+}$, etc. $)$, which reflects the state of the bacterial physiology. A decline

Table 1 Antibacterial activity of peptides against pathogenic strains.

\begin{tabular}{|c|c|c|c|c|c|c|c|}
\hline \multirow[t]{2}{*}{ Peptides } & \multicolumn{7}{|l|}{$\operatorname{MICs}(\mu \mathrm{M})$} \\
\hline & S. aureus & S. epidermidis ATCC & S. pneumonia & S. suis CVCC & E. coli ATCC & S. pullorum & S. Enteritidis CVCC \\
\hline & & & & & & & \\
\hline ID13 & 0.95 & 1.91 & 0.95 & 0.95 & $>30.50$ & $>30.50$ & $>30.50$ \\
\hline DLP4 & 3.75 & 14.99 & 7.50 & 3.75 & $>29.98$ & $>29.98$ & $>29.98$ \\
\hline $\operatorname{Van}^{\mathrm{a}}$ & 0.67 & 0.67 & 0.34 & 0.17 & 86.15 & 86.15 & 86.15 \\
\hline
\end{tabular}

${ }^{\mathrm{a}}$ Vancomycin 


\section{a}
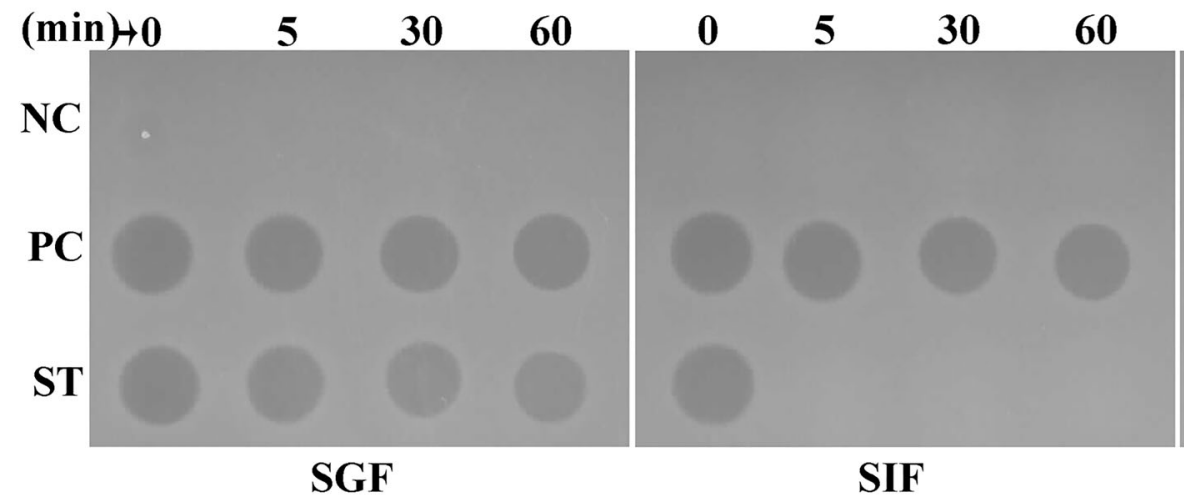

0

5

30

60

b

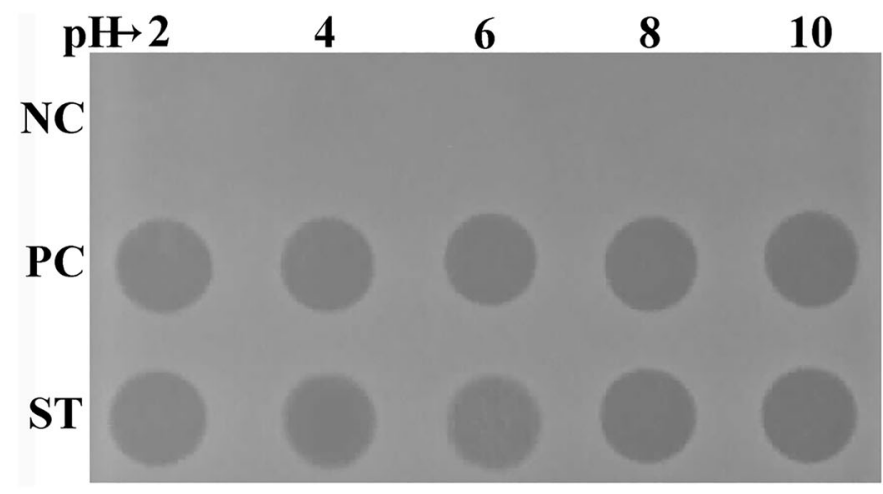

c

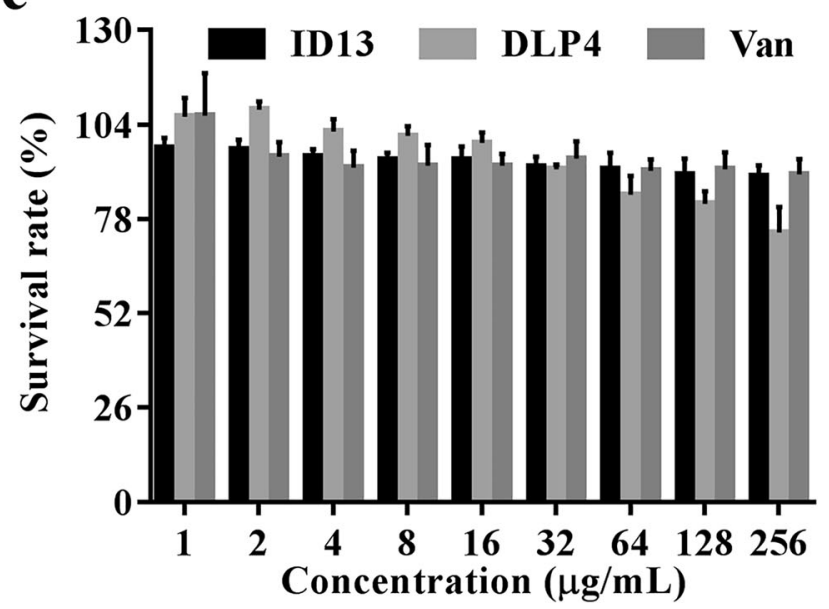

stability tested of peptide ID13 prepared in biological fluids. c Cytotoxicity of peptides ID13, DLP4, and vancomycin (Van) toward $\operatorname{MEECs}(n=4)$
Fig. 1 Bioavailability of peptide ID13. a The stability of peptide ID13 in simulated gastric fluid (SGF), simulated intestinal fluid (SIF), serum, and b different $\mathrm{pH}$ buffers. $\mathrm{NC}$, negative control; PC, positive control; ST, of $\Delta \Psi$ will result in the inhibition of energy metabolism (Shapiro 2000; van der Stel et al. 2017).

As shown in Supplementary Table S1, the genes (mnhABCDEHF, fabD, lytM, ureF, and ipdC) encoding ion binding and transport proteins were reduced by 1.1and 3.2-fold, while the other ones (ebh, $m t l A, s d r C, s d r D$, $s d r E, \operatorname{cop} A, h u t G$, and $z i n T)$ were upregulated. The decreased expression of $m n h A B C D E H F$, specifically responsible for $\mathrm{Na}^{+} / \mathrm{H}^{+}$antiporter, suggested a decline of $\Delta \Psi$ and energy biosynthesis (Castro et al. 2016). The genes (nreB, ftnA, narGHT, nasD, pflAB, adh1, ldhAB, and natA) for energy metabolism were upregulated (1.3 to 7.8 -fold), while $\operatorname{tr} x A B$ (encoding thioredoxin and thioredoxin reductase) (Villanueva et al. 2016), glpD (encoding glycerol-3phosphate dehydrogenase) (Szalus-Jordanow et al. 2018), fda (encoding fructose-bisphosphate aldolase class 1) (Capodagli et al. 2014), pgk (encoding phosphoglycerate kinase) (Liew et al. 2015), and eno (encoding enolase) (Dai et al. 2019) were downregulated. The results indicated that
ID13 might negatively affect the endergonic processes such as ATP synthesis through mnhABCDEHF inhibition.

\section{Pathogenicity-related genes}

S. aureus causes host infections through surface colonization, entry, and invasion process (Bayer et al. 1996). Colonization is mediated by the microbial surface component recognizing adhesive matrix molecules (MSCRAMMs), mainly encoded by $c l f B, f n b A$, eno, ebh, spa, agrABC, and $s d r C D E$ (Speziale et al. 2009), which are under control of sar and $a g r$, and $a g r$ is also partly regulated by sar (Azara et al. 2017; Speziale et al. 2009). The extracellular DNA is important in the course of biofilm formation, and it is regulated by cid and lrg operon, which induces and inhibits cell lysis, respectively (Rice et al. 2007; Sadykov and Bayles 2012; Shen et al. 2015). Meanwhile, LytSR system regulates the expression of lrg; disruption of the lytSR genes induces increased autolysis (Sadykov and Bayles 2012). In addition, the genes secA 
a

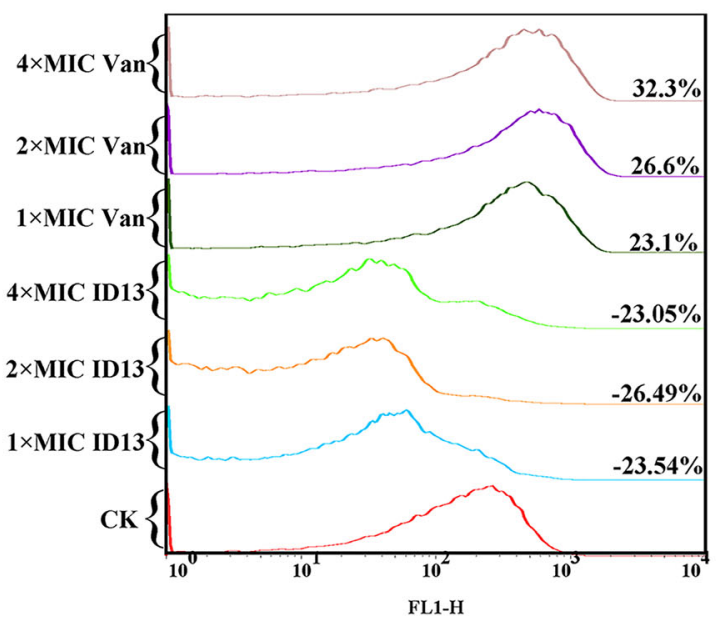

c

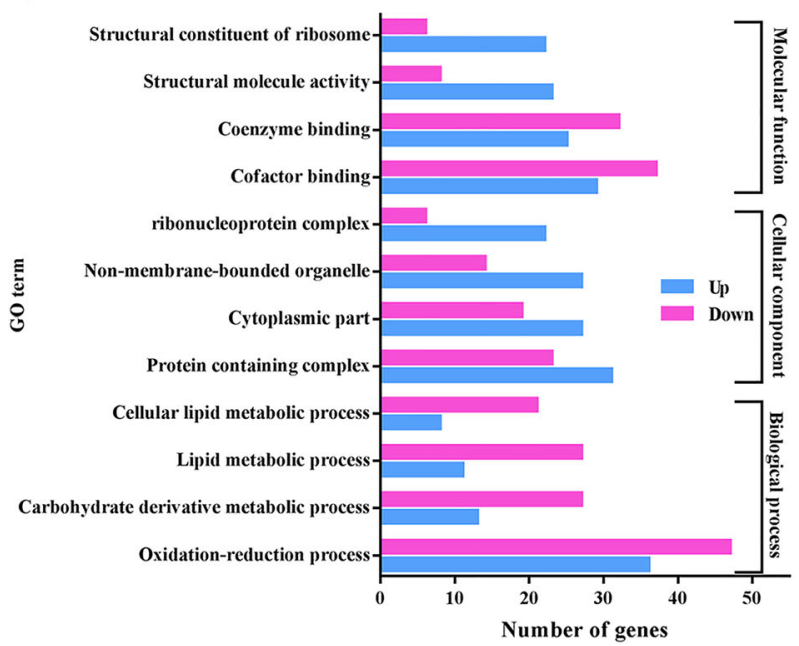

b

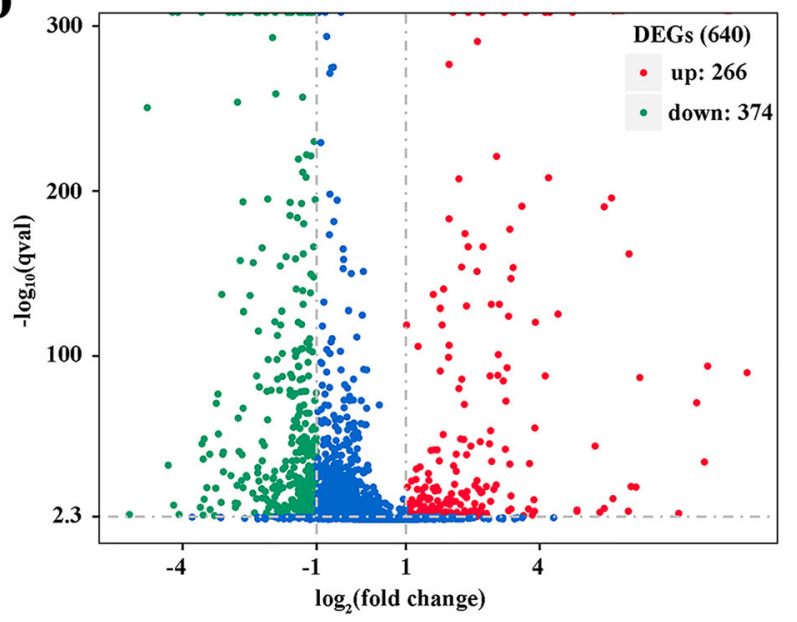

d

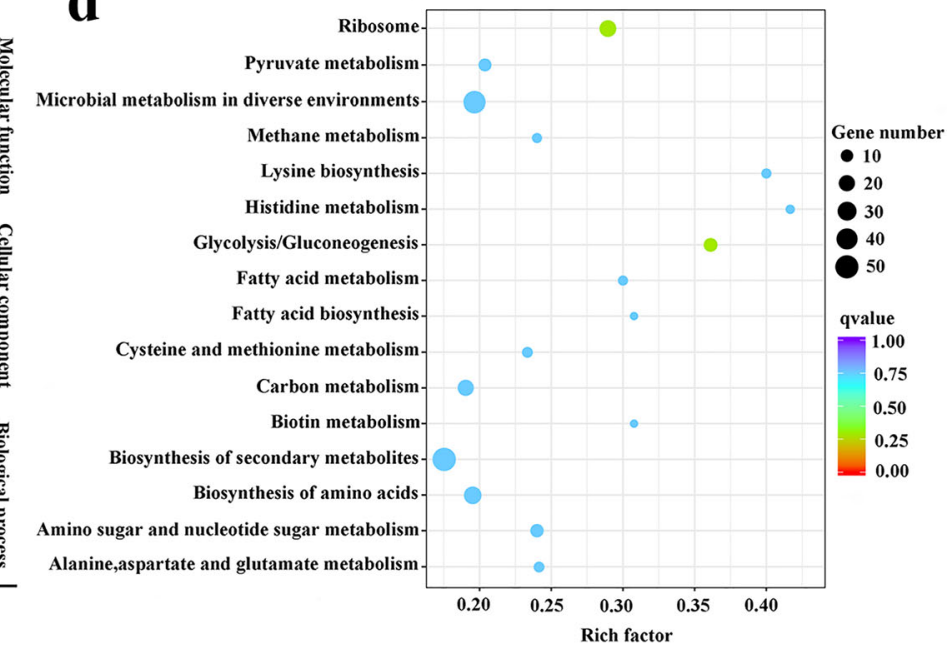

Fig. 2 The effects of peptide ID13 on S. aureus. a The membrane depolarization, b differential gene expression, $\mathbf{c}$ enriched GO terms, and $\mathbf{d}$ KEGG pathway of ID13-treated S. aureus CVCC 546

(encoding a key component of the general bacterial secretion system required for toxins secretion), hly (encoding hemolysin), and cap (encoding capsular polysaccharide) also play various roles in bacterial evasion of the host immune defense (Jin et al. 2015; Weidenmaier and Lee 2017; Zhang and Austin 2005).

As shown in Supplementary Table S2, the transcript levels of $c l f B, e b h, s p a, a g r A B C$, and $s d r C D E$ but not $f n b A$ and eno were elevated 1.8 to 6.2 fold. It showed that ID13 exhibited positive effect on the expression of most MSCRAMMencoding genes. Meanwhile, the expression of positive regulatory genes of MSCRAMMs (agrABC and $\operatorname{sar} S$ ) was also upregulated (1.8 to 3.2- fold). The transcript levels of the positive regulator of autolysis cidA remarkably decreased by 4.2 fold, while the expression of negative regulator $\operatorname{lrg} B$ increased by 2.5 fold. It indicated that $S$. aureus might protect itself from being induced autolysis by ID13. Due to the increased expression of $\sec A$ for toxin secretion, hly expression was also elevated. Compared with the control, ID13-treated
S. aureus significantly downregulated the levels of genes (capABCDGLMN) for biofilm formation. These results suggested that ID13 affected $S$. aureus biofilm formation by inhibiting capsule polysaccharide synthesis, thereby reducing bacterial pathogenicity.

\section{Efficacies of peptide ID13 in vitro}

\section{Synergism of peptide ID13 with antibiotics}

The combination of antimicrobial peptides with antibiotics is an efficacious strategy to combat antibiotic resistance of bacteria (Zharkova et al. 2019). As shown in Fig. 3a, the FICI values for ID13 and vancomycin (Van), ampicillin (Amp), rifampin (Rif), or ciprofloxacin (Cip) ranged from 0.1875 to 0.375 , indicating the synergistic effect. It demonstrated that the combined application of peptide ID13 with antibiotics has a potential to be used to inhibit the growth of $S$. aureus $\mathrm{CVCC}$ 546. 
a

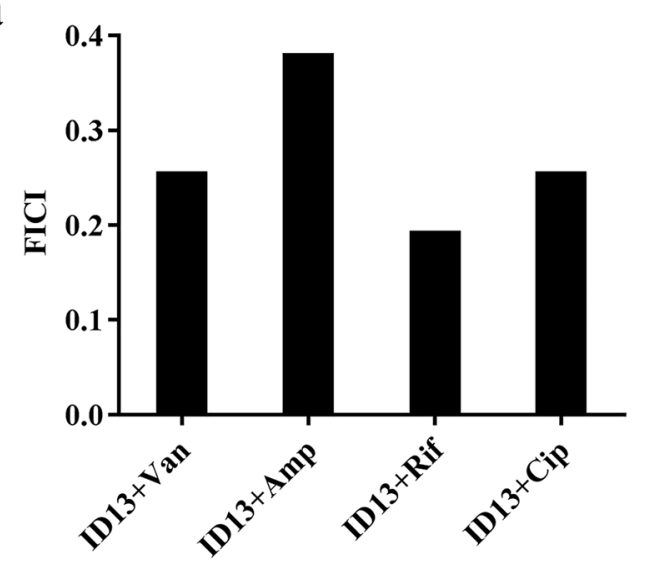

c

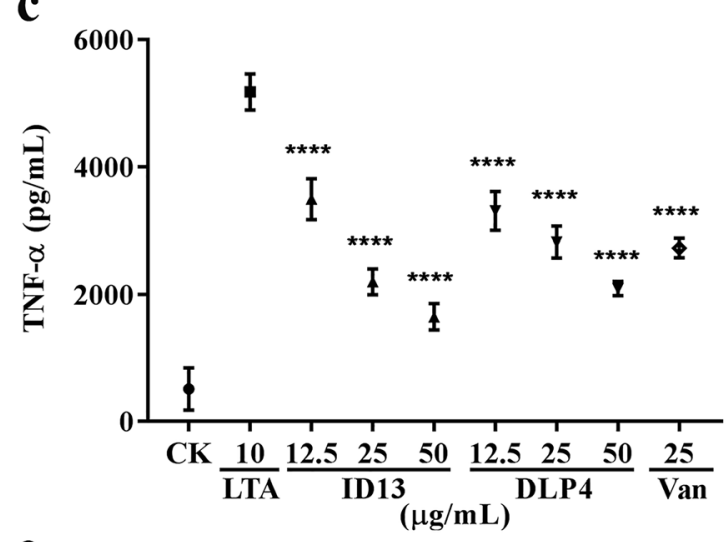

e

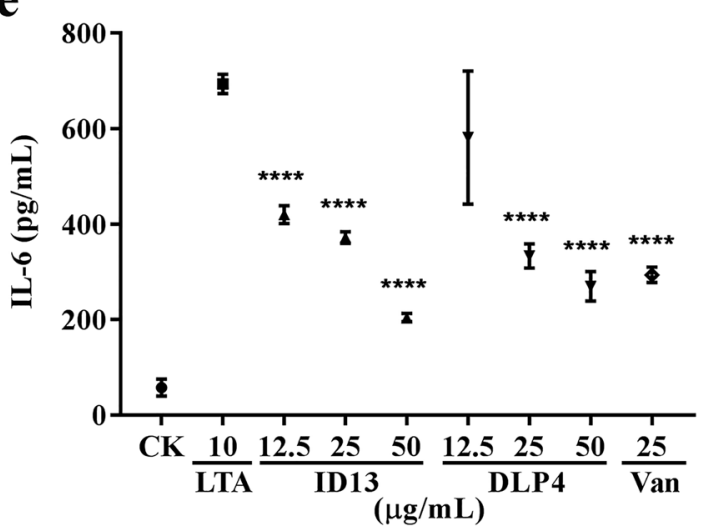

Fig. 3 In vitro efficacy of peptide ID13. a Combined application of peptide ID13 with antibiotics against $S$. aureus CVCC 546, vancomycin, ampicillin, rifampin, and ciprofloxacin that are represented by Van, Amp, Rif, and Cip, respectively, and $\mathbf{b}$ antimicrobial activity against intracellular $S$. aureus CVCC 546. Inhibition of LTA-induced

\section{Intracellular antimicrobial activity}

As shown in Fig. 3b, ID13, DLP4, and vancomycin could enter MEEC cells and kill over $99 \%$ of $S$. aureus CVCC 546 in a dose-dependent manner. The killing rate of $200-\mu \mathrm{g} /$ mL ID13 and DLP4 was up to $99.92 \%$ and $99.90 \%$, slightly lower than that of vancomycin $(99.99 \%)$. This result b

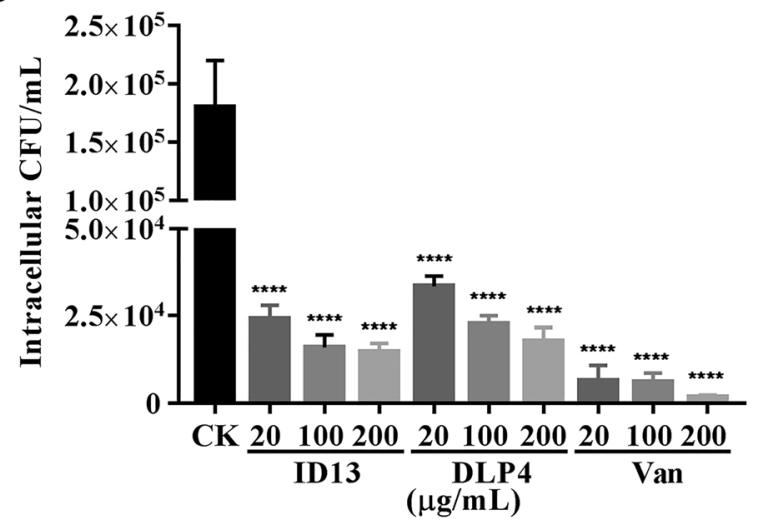

d
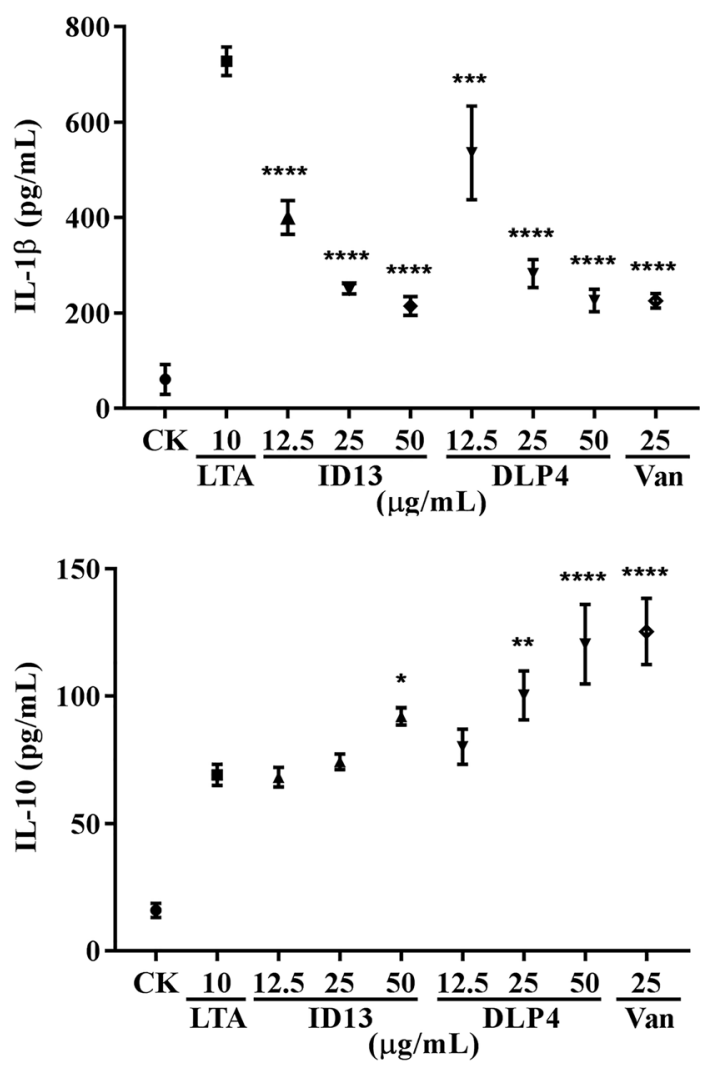

cytokines c TNF- $\alpha$, d IL-1 $\beta$, e IL-6, and f IL-10 from RAW 264.7. Statistical significance of differences between experimental and LTA groups were determined using the one-way ANOVA and Dunnett's multiple comparison. $* p<0.05, * * p<0.01, * * * p<0.001$, **** $p<0.0001$

demonstrated that ID13 exhibited remarkable bactericidal efficiency against intracellular S. aureus.

\section{Anti-inflammatory activity}

As shown in Fig. 3c-f, LTA could stimulate the production of TNF- $\alpha$, IL-1 $\beta$, IL-6, and IL-10 in RAW 264.7. After 
treatment with ID13, DLP4, and vancomycin, the proinflammatory cytokines TNF- $\alpha$, IL- $1 \beta$, and IL- 6 decreased in a concentration-dependent manner in all tests. After incubation with $50-\mu \mathrm{g} / \mathrm{mL}$ ID13, the levels of cytokines TNF- $\alpha$ $(1648.57 \pm 209.29 \mathrm{pg} / \mathrm{mL})$, IL-6 $(203.9 \pm 8.65 \mathrm{pg} / \mathrm{mL})$, and IL-1 $\beta(215.17 \pm 19.54 \mathrm{pg} / \mathrm{mL})$ were reduced by $68.18 \%$, $70.61 \%$, and $70.44 \%$, higher than those of DLP4. In contrast, after treatment with $25-\mu \mathrm{g} / \mathrm{mL}$ ID13, anti-inflammatory cytokine IL-10 was increased by $7.47 \%$, lower than that of DLP4 $(45.09 \%)$ and vancomycin $(81.26 \%)$. The results suggest that ID13 has the ability to suppress pro-inflammatory responses in macrophages.

\section{Efficacy of peptide ID13 in vivo}

Given its low cytotoxicity and stability in SGF, SIF, serum, and different $\mathrm{pH}$ buffers, the in vivo therapeutic potential of peptide ID13 was further investigated through an endometritis model of mouse.

\section{Morphology changes in the mice uterus}

By anatomy, the uterus showed normal morphology and had no adhesion with the surrounding tissues in the blank control; comparatively, in the negative control, the uterus appeared abnormal, including enlarged uterine volume; dilated and tortuous lumen; thinned uterine wall; yellow pus or clear liquid in the lumen; and swollen, congested, and dark red perimetrium surface (Supplementary Fig. S1).

\section{Leukocytes and pathogens analysis}

In the negative and blank controls, it was observed significant changes in the white blood cells (Supplementary Table S3). The number of white blood cells $\left(14.56 \pm 3.0010^{9}\right.$ cells $\left./ \mathrm{L}\right)$, neutrophils $\left(9.65 \pm 2.0010^{9}\right.$ cells $\left./ \mathrm{L}\right)$, and lymphocytes $(3.25 \pm$ $0.8310^{9}$ cells/L) in the negative control was significantly higher than those in the blank control. The percentage of neutrophils was increased remarkably by $66.24 \pm 1.51 \%$, while that of lymphocytes was decreased significantly by $22.24 \pm$ $2.33 \%$. The result indicated that endometritis can be established in mice by intrauterine inoculation of S. aureus CVCC 546.

To isolate and identify $S$. aureus CVCC 546, homogenized uterine samples diluted 1:10 (w/v) in PBS were dropped on BP agar supplemented with potassium tellurite yolk enrichment broth, and then the isolates were further conformed through 16S rRNA gene sequence analysis. As shown in Supplementary Fig. S2a, S. aureus CVCC 546 isolates were found to be the major bacterial pathogen isolated from uteri of mouse; after amplicon and molecular identification (Supplementary Fig. S2b), 16S rRNA gene sequence BLAST on NCBI website (https://blast.ncbi.nlm.nih.gov/ Blast.cgi) showed that the isolated pathogen was most similar to $S$. aureus according to taxonomy report (Supplementary Fig. S2c).

\section{Ameliorating pathological uteri}

Histopathological analysis of uteri by H\&E staining showed no histological abnormality that was found in the blank control with normal endometrium, myometrium, and perimetrium (Fig. 4a). Comparatively, structures of the uteri in the negative control were obviously destroyed; the glands of the endometrium were atrophied and even disappeared; a large number of inflammatory cells (mainly neutrophils and lymphocytes, accompanied by a small number of monocytes) were observed in the stroma of the endometrium as well as fibrous tissue hyperplasia. In addition, inflammation also caused the shedding of epithelial cells into uterine cavity (Fig. 4b). These results showed that the endometritis model of mouse was successfully established by infection of S. aureus CVCC 546.

After administration of ID13 $(5,10$, or $15 \mathrm{mg} / \mathrm{kg})$, pathological conditions were improved rapidly in a dose-dependent manner (Fig. 4d-f). Only a small amount of scattered inflammatory cells were observed in part of uterus after treatment with $10-\mathrm{mg} / \mathrm{kg}$ vancomycin or $15-\mathrm{mg} / \mathrm{kg}$ peptide ID13 (Fig. 4 $\mathrm{c}$ and $\mathrm{f}$ ). The results suggested that similar to vancomycin, ID13 could ameliorate the pathological outcome of mouse uteri infected with $S$. aureus CVCC 546.

\section{Attenuating inflammatory cytokines}

As shown in Fig. 5, the production of inflammatory cytokines TNF- $\alpha$, IL- $1 \beta$, IL- 6 , and IL-10 in the negative control (PBS) was remarkably increased in serum from mice infected with S. aureus CVCC 546. After treatment with ID13, the levels of inflammatory cytokines TNF- $\alpha$, IL- $1 \beta$, IL- 6 , and IL-10 significantly decreased in a dose-dependent manner. Administration with $15-\mu \mathrm{g} / \mathrm{mL}$ ID13 resulted in a reduction of cytokines TNF- $\alpha(107.80 \mathrm{pg} / \mathrm{mL}), \mathrm{IL}-6(163.14 \mathrm{pg} / \mathrm{mL})$, IL-1 $\beta(218.64 \mathrm{pg} / \mathrm{mL})$, and IL-10 $(55.48 \mathrm{pg} / \mathrm{mL})$, which was roughly equivalent to $10 \mu \mathrm{g} / \mathrm{mL}$ vancomycin (TNF- $\alpha, 124.92$ pg/mL; IL-6, 134.74 pg/mL; IL-1 $\beta, 198.72$ pg/mL; IL-10, $48.20 \mathrm{pg} / \mathrm{mL}$ ).

\section{Regulating NF-KB signaling pathway}

TLR2 is critical for the host immune cells and can recognize microbe-associated pathogenic molecules (e.g., LTA), which stimulates the production of inflammatory cytokines and results in the activation of NF- $\mathrm{KB}$ signaling pathway (Goldstein 2004). To explore the antiinflammatory mechanism of peptide ID13, the expression of TLR2 and NF-KB was analyzed by western blot. As shown in Fig. 6, the relative content of TLR2 in the negative control (PBS) was significantly higher than that in 

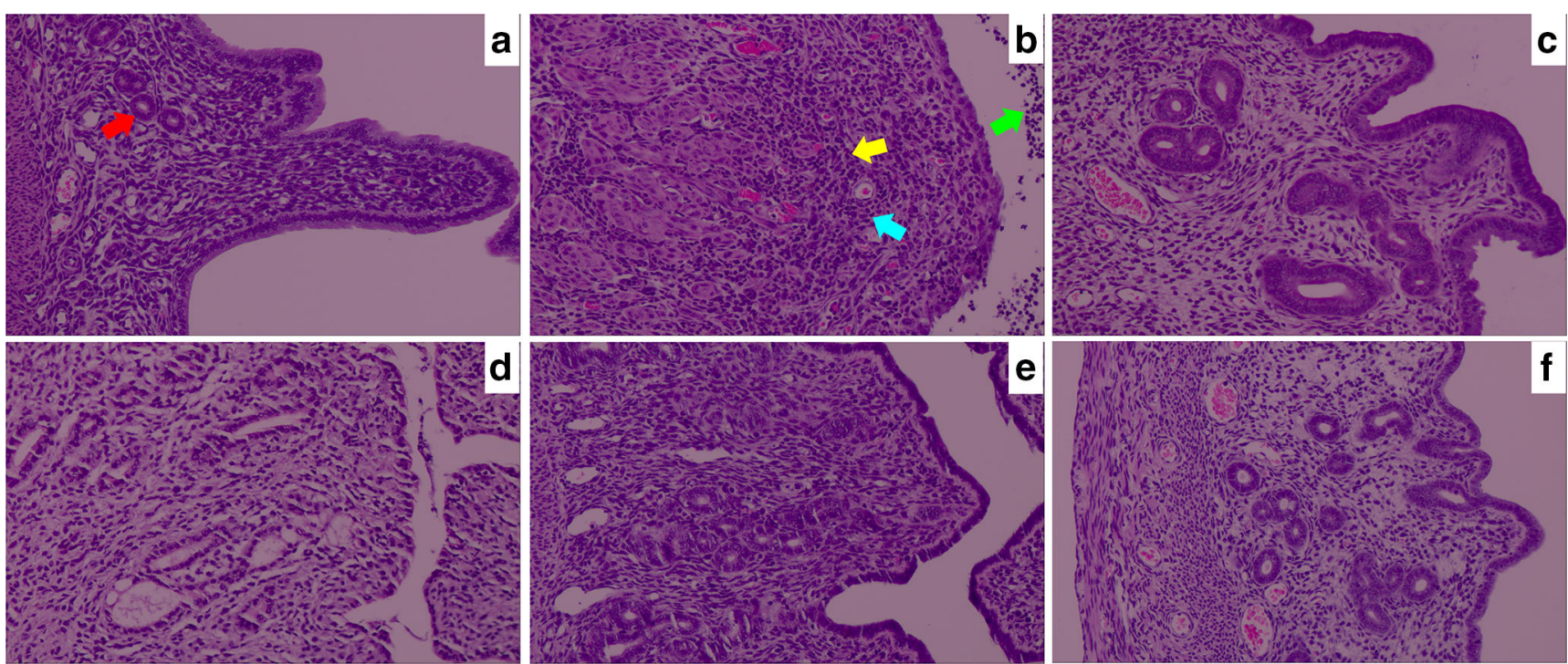
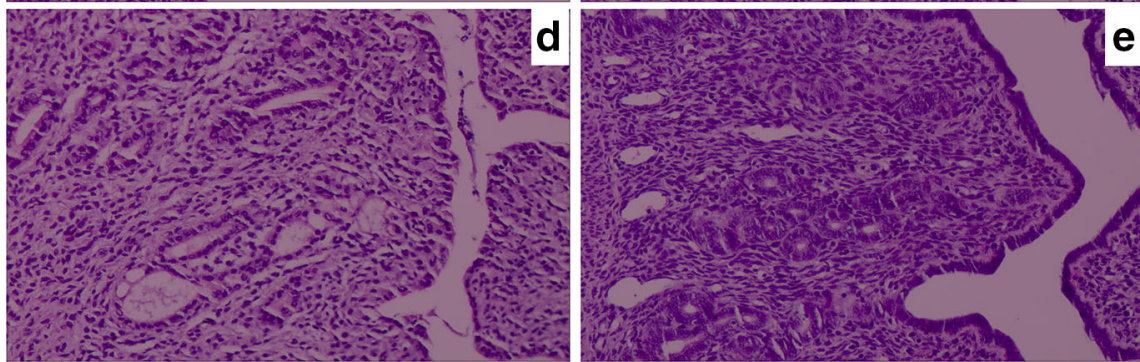

and $15 \mathrm{mg} / \mathrm{kg}$ peptide ID13, respectively. Red arrow, gland; yellow arrow, neutrophils; cyan arrow, lymphocytes; green arrow, the shedding of epithelial cells into uterine cavity

\section{Discussion}

S. aureus is a common pathogen that can cause post-partum clinical and subclinical endometritis in humans and animals (Turner et al. 2012; Zhang et al. 2017). During the long-term use of antibiotics, $S$. aureus has been found to develop resistance (Hiramatsu 2001; Lai et al. 2018; Pirolo et al. 2019). To
Fig. 5 Effects of ID13 on inflammatory cytokines a TNF- $\alpha$, b IL-1 $\beta$, c IL-6, and $\mathbf{d}$ IL-10 in serum from mice $(n=5)$.

Statistical significance of differences between experimental and negative control (PBS) was determined using the one-way ANOVA and Dunnett's multiple comparison. $* * p<0.01$, *** $p<$ 0.001 , **** $p<0.0001$. a
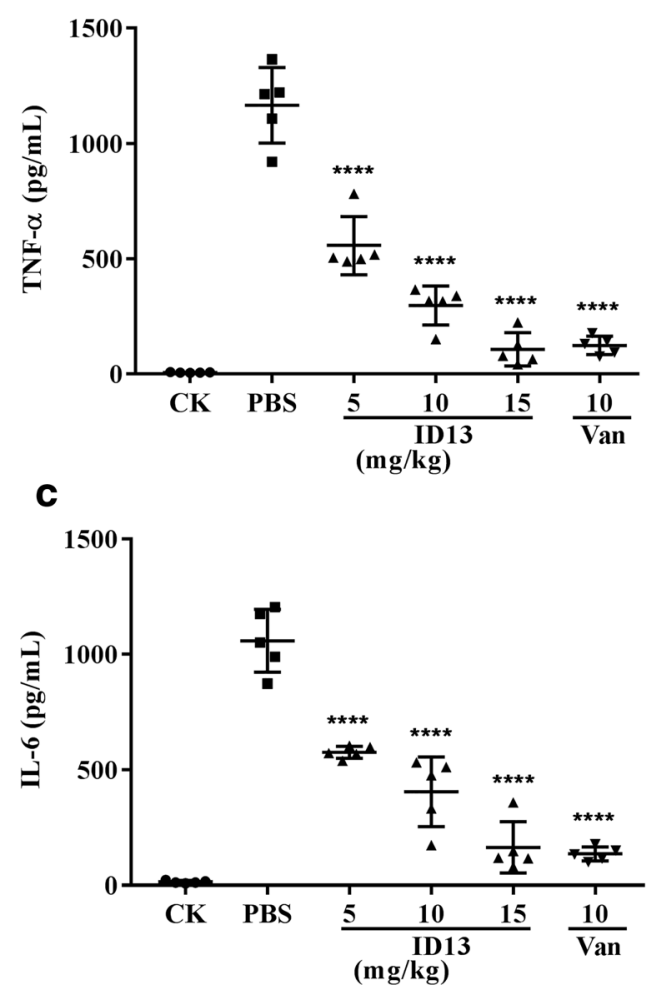

b

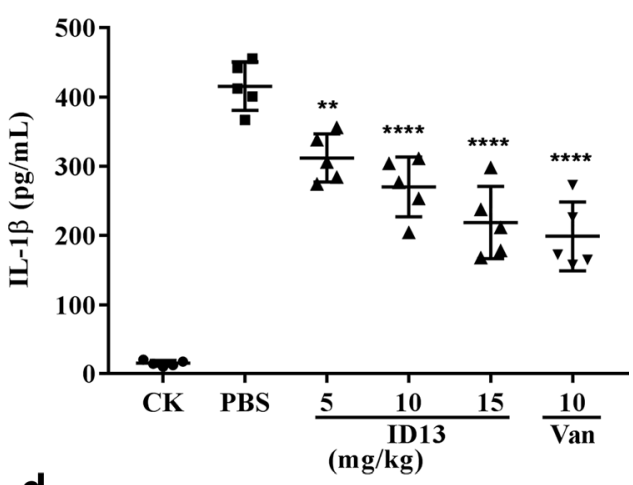

d

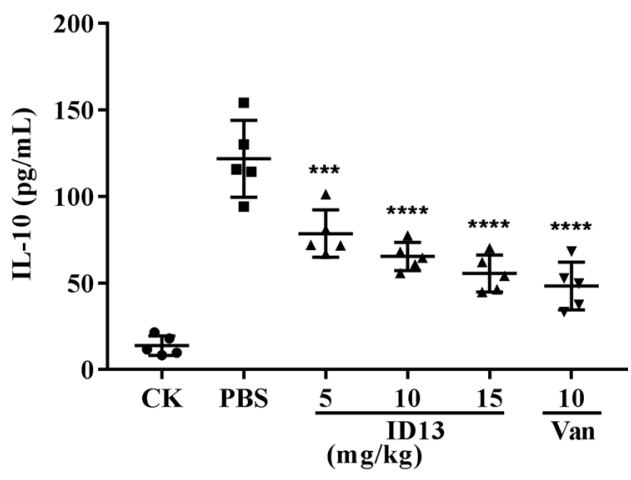



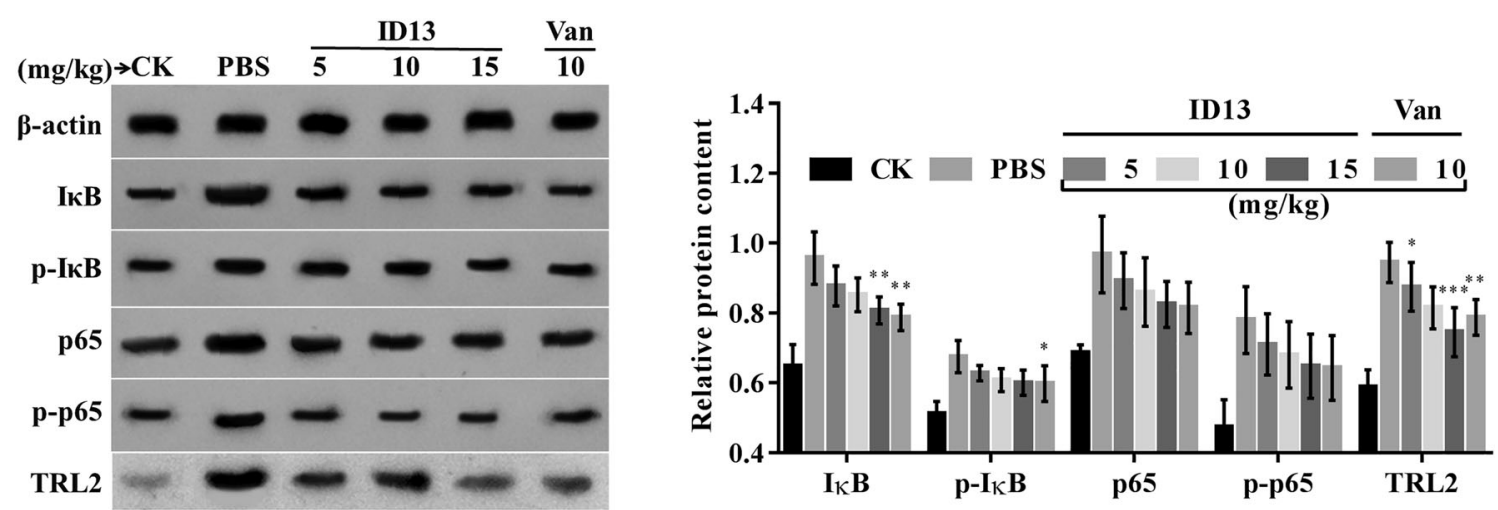

Fig. 6 Effects of peptide ID13 on TLR2-NF-KB signaling $(n=5)$. Statistical significance of differences between experimental and negative control (PBS) was determined using the one-way ANOVA and Dunnett's multiple comparison. $* p<0.05, * * p<0.01, * * * p<0.001$

combat antibiotic-resistant $S$. aureus, insect defensins are promising candidates for the development of novel antimicrobials (Koehbach 2017). In this study, the efficacies of a designed peptide ID13 from insect defensin DLP4 were assessed against $S$. aureus CVCC 546 in vitro and in vivo.

Antimicrobial activity, stability, and cytotoxicity are important factors in the preliminary screening of candidate peptides. ID13 displayed potent antimicrobial activity (MICs 0.95 1.91 $\mu \mathrm{M}$ ) against Gram-positive bacteria (Table 1); high stability in SGF (90.79\%), serum (99.54\%), and different $\mathrm{pH}$ buffers (> 99\%); and lower cytotoxicity (89.62\% viability) toward MEECs than its parent peptide DLP4 (74.14\% viability) (Fig. 1), which may be attributed to its increased hydrophobicity, decreased charge, and shorter amino acid side chain (Li et al. 2020). These results also suggested a good bioavailability for ID13.

Structure analysis showed that ID13 is an amphipathic, cationic, and $\mathrm{CS} \alpha \beta$ peptide (Li et al. 2020), indicating the high affinity to anionic bacterial membranes, which was exactly confirmed in membrane depolarization of ID13 (Fig. 2a). Membrane potential is maintained by a substantial proportion of the energy and electron (Kinkel et al. 2016); depolarization of membrane disrupts the energy generation and electron transfer, which is specifically reflected in the depression of $\mathrm{Na}(+) / \mathrm{H}(+)$ pump activity (Supplementary Table S1) (Castro et al. 2016). The cationic antimicrobial peptide (Temporin L$\mathrm{NH}_{2}$, ovispirin-1- $\mathrm{NH}_{2}$, and dermaseptin K4-S4 (1-16)- $\mathrm{NH}_{2}$ )treated $S$. aureus showed a downregulation of nar, nas, and adh1(Pietiainen et al. 2009), which were increased in ID13treated $S$. aureus in our study (Supplementary Table S1). cap is responsible for capsular polysaccharide expression (Gill et al. 2005) and plays an important role in biofilms formation (Prokopovich and Perni 2009); a significant downregulation of cap expression (Supplementary Table S2) implies a reduced bacterial infection (Weidenmaier and Lee 2017).

$S$. aureus can internalize into host cells to form an intracellular pathogen pool, thereby avoiding being killed by traditional antibiotics and causing further damages (Al Kindi et al.
2019; Wang et al. 2019). Meanwhile, the bacterial cell wall component LTA is an important immunostimulatory virulence factor in S. aureus infections (Ginsburg 2002), can activate pro-inflammatory signaling (Rockel and Hartung 2012), and promotes the development of sepsis (Hotchkiss and Karl 2003). NZ2114, a variant of the fungus-derived defensin plectasin from Pseudoplectania nigrella, is a $\operatorname{CS} \alpha \beta$ peptide, which could be internalized into the cells via clathrinmediated endocytosis and macropinocytosis, and distributed in the cytoplasm. It exhibits intracellular bacteriostatic efficacy with the reduction of $S$. aureus colony counting (Wang et al. 2018). ID13 shares the same structure with NZ2114 and thus may have a similar mechanism of cell internalization to kill intercellular $S$. aureus like NZ2114 does. In present study, almost all of the intracellular $S$. aureus CVCC 546 were killed by ID13 (99.92\%), slightly lower than that of vancomycin $(99.99 \%)$ (Fig. 3b). In recent years, many peptides such as Temporins A, NZ2114, and LL-37 have been proved to exhibit a high efficiency against intracellular $S$. aureus in host cells (Di Grazia et al. 2014; Noore et al. 2013; Wang et al. 2018). Moreover, ID13 could inhibit the production of inflammation cytokines in RAW 246.7 and in mice challenged with LTA or S. aureus CVCC 546 (Figs. 3c-e and 5a-c). However, the level of IL-10 decreased in mice (Fig. 5d) might attribute to the effects of different kind of immune cells induced by LTA and $S$. aureus CVCC 546 in vitro and in vivo, respectively. Also, ID13 could attenuate the phosphorylation of NF- $\kappa B$ in mice (Fig. 6), thereby downregulating the expression of downstream pro-inflammatory cytokines (Fig. 5a-c). These results suggested that ID13 can improve the pathological conditions of mouse endometritis (Fig. 4c-f).

In conclusion, peptide ID13 exhibited stable antimicrobial activity in SGF and serum against $S$. aureus CVCC 546 and lower cytotoxicity than its parent peptide DLP4. ID13 caused a depolarization of bacterial membrane and downregulated the expression of genes involved in membrane potential maintenance and biofilm formation. ID13 had a synergistic effect with ancient antibiotics and intracellular antimicrobial activity 
of $S$. aureus CVCC 546 in MEECs. ID13 improved pathological conditions of endometritis of mouse induced by $S$. aureus and inhibited the production of TNF- $\alpha$, IL-1ß, IL-6, and IL10. Furthermore, TLR2-NF- $\mathrm{B}$ signaling pathway was significantly suppressed by ID13. These results suggest that ID13 could be a potential antimicrobial for clinical application.

Author contributions Jianhua Wang, Ruoyu Mao, Da Teng, Xiumin Wang, and Bing Li conceived and designed experiments. Bing Li carried out all the experiments. Na Yang, Yuxue Shan, and Ya Hao prepared partial materials in laboratory; Da Teng, Ruoyu Mao, and Jianhua Wang contributed in writing. Jianhua Wang contributed in funding acquisition. Ya Hao contributed to materials and reagents. Huan Fan coordinated partially support of human resources during running.

Funding information This study was supported by the National Natural Science Foundation of China (Grants 31872393, 31772640, and 31702146), the AMP Direction of the National Innovation Program of Agricultural Science and Technology in CAAS (Grant CAAS-ASTIP2013-FRI-02), and its Key Project of Alternatives to Antibiotics for Feed Usages (Grant CAAS-ZDXT2018008).

\section{Compliance with ethical standards}

Conflict of interest The authors declare that they have no conflict of interest.

Ethical statement The mouse experiment was performed according to the Animal Care and Use Committee of the Feed Research Institute of Chinese Academy of Agricultural Sciences (CAAS) and approved by the Laboratory Animal Ethical Committee and its Inspection of the Feed Research Institute of CAAS (AEC-CAAS-20090609).

\section{References}

Ahn HS, Cho W, Kang SH, Ko SS, Park MS, Cho H, Lee KH (2006) Design and synthesis of novel antimicrobial peptides on the basis of alpha helical domain of Tenecin 1, an insect defensin protein, and structure-activity relationship study. Peptides 27(4):640-648

Al Kindi A, Alkahtani AM, Nalubega M, El-Chami C, O'Neill C, Arkwright PD, Pennock JL (2019) Staphylococcus aureus internalized by skin keratinocytes evade antibiotic killing. Front Microbiol 10:2242

Andersson DI, Hughes D, Kubicek-Sutherland JZ (2016) Mechanisms and consequences of bacterial resistance to antimicrobial peptides. Drug Resist Updat 26:43-57

Azara E, Longheu C, Sanna G, Tola S (2017) Biofilm formation and virulence factor analysis of Staphylococcus aureus isolates collected from ovine mastitis. J Appl Microbiol 123(2):372-379

Barreto-Santamaria A, Patarroyo ME, Curtidor H (2019) Designing and optimizing new antimicrobial peptides: all targets are not the same. Crit Rev Clin Lab Sci 56(6):351-373

Bayer MG, Heinrichs JH, Cheung AL (1996) The molecular architecture of the sar locus in Staphylococcus aureus. J Bacteriol 178(15): 4563-4570

Benincasa M, Pelillo C, Zorzet S, Garrovo C, Biffi S, Gennaro R, Scocchi M (2010) The proline-rich peptide Bac7(1-35) reduces mortality from Salmonella typhimurium in a mouse model of infection. BMC Microbiol 10:178

Capodagli GC, Lee SA, Boehm KJ, Brady KM, Pegan SD (2014) Structural and functional characterization of methicillin-resistant
Staphylococcus aureus's class IIb fructose 1,6-bisphosphate aldolase. Biochemistry 53(48):7604-7614

Castro PJ, Silva AF, Marreiros BC, Batista AP, Pereira MM (2016) Respiratory complex I: a dual relation with $\mathrm{H}^{+}$and $\mathrm{Na}^{+}$? Biochim Biophys Acta 1857(7):928-937

Cerovsky V, Slaninova J, Fucik V, Monincova L, Bednarova L, Malon P, Stokrova J (2011) Lucifensin, a novel insect defensin of medicinal maggots: synthesis and structural study. Chembiochem 12(9):13521361

Coyne LA, Latham SM, Dawson S, Donald IJ, Pearson RB, Smith RF, Williams NJ, Pinchbeck GL (2019) Exploring perspectives on antimicrobial use in livestock: a mixed-methods study of UK pig farmers. Front Vet Sci 6:257

Coyne LA, Latham SM, Williams NJ, Dawson S, Donald IJ, Pearson RB, Smith RF, Pinchbeck GL (2016) Understanding the culture of antimicrobial prescribing in agriculture: a qualitative study of UK pig veterinary surgeons. J Antimicrob Chemother 71(11):3300-3312

da Cunha NB, Cobacho NB, Viana JFC, Lima LA, Sampaio KBO, Dohms SSM, Ferreira ACR, de la Fuente-Nunez C, Costa FF, Franco OL, Dias SC (2017) The next generation of antimicrobial peptides (AMPs) as molecular therapeutic tools for the treatment of diseases with social and economic impacts. Drug Discov Today 22(2):234-248

Dai J, Wu S, Huang J, Wu Q, Zhang F, Zhang J, Wang J, Ding Y, Zhang S, Yang X, Lei T, Xue L, Wu H (2019) Prevalence and characterization of Staphylococcus aureus isolated from pasteurized milk in China. Front Microbiol 10:641

Di Grazia A, Luca V, Segev-Zarko LA, Shai Y, Mangoni ML (2014) Temporins A and B stimulate migration of HaCaT keratinocytes and kill intracellular Staphylococcus aureus. Antimicrob Agents Chemother 58(5):2520-2527

Eslami M, Bolourchi M, Seifi HA, Asadi F, Akbari R (2015) Treatment of clinical endometritis in dairy cows by previously used controlled internal drug release devices. Theriogenology 84(3):437-445

Fluit AC (2012) Livestock-associated Staphylococcus aureus. Clin Microbiol Infect 18(8):735-744

Foster AP (2012) Staphylococcal skin disease in livestock. Vet Dermatol 23(4):342-351 e63

Gilbert RO, Shin ST, Guard CL, Erb HN, Frajblat M (2005) Prevalence of endometritis and its effects on reproductive performance of dairy cows. Theriogenology 64(9):1879-1888

Gill SR, Fouts DE, Archer GL, Mongodin EF, Deboy RT, Ravel J, Paulsen IT, Kolonay JF, Brinkac L, Beanan M, Dodson RJ, Daugherty SC, Madupu R, Angiuoli SV, Durkin AS, Haft DH, Vamathevan J, Khouri H, Utterback T, Lee C, Dimitrov G, Jiang L, Qin H, Weidman J, Tran K, Kang K, Hance IR, Nelson KE, Fraser CM (2005) Insights on evolution of virulence and resistance from the complete genome analysis of an early methicillin-resistant Staphylococcus aureus strain and a biofilm-producing methicillinresistant Staphylococcus epidermidis strain. J Bacteriol 187(7): $2426-2438$

Ginsburg I (2002) Role of lipoteichoic acid in infection and inflammation. Lancet Infect Dis 2(3):171-179

Goldstein DR (2004) Toll-like receptors and other links between innate and acquired alloimmunity. Curr Opin Immunol 16(5):538-544

Hiramatsu K (2001) Vancomycin-resistant Staphylococcus aureus: a new model of antibiotic resistance. Lancet Infect Dis 1(3):147-155

Hotchkiss RS, Karl IE (2003) The pathophysiology and treatment of sepsis. N Engl J Med 348(2):138-150

Jin J, Cui J, Chaudhary AS, Hsieh YH, Damera K, Zhang H, Yang H, Wang B, Tai PC (2015) Evaluation of small molecule SecA inhibitors against methicillin-resistant Staphylococcus aureus. Bioorg Med Chem 23(21):7061-7068

Kang HK, Kim C, Seo CH, Park Y (2017) The therapeutic applications of antimicrobial peptides (AMPs): a patent review. J Microbiol 55(1): $1-12$ 
Kindmark H, Kohler M, Brown G, Branstrom R, Larsson O, Berggren PO (2001) Glucose-induced oscillations in cytoplasmic free $\mathrm{Ca}^{2+}$ concentration precede oscillations in mitochondrial membrane potential in the pancreatic beta-cell. J Biol Chem 276(37):34530 34536

Kinkel TL, Ramos-Montanez S, Pando JM, Tadeo DV, Strom EN, Libby SJ, Fang FC (2016) An essential role for bacterial nitric oxide synthase in Staphylococcus aureus electron transfer and colonization. Nat Microbiol 2:16224

Koehbach J (2017) Structure-activity relationships of insect defensins. Front Chem 5:45

Lai CC, Lee CM, Chiang HT, Lu MC, Wang LF, Tsai TL, Kang MY, Jan YN, Lo YT, Ko WC, Tseng SH, Hsueh PR (2018) Methicillinresistant Staphylococcus aureus sequence type 45 with high rates of ciprofloxacin and tetracycline resistance in the residents and environments of long-term care facilities in Taiwan. J Infect 76(3): 305-307

Landon C, Barbault F, Legrain M, Guenneugues M, Vovelle F (2008) Rational design of peptides active against the Gram positive bacteria Staphylococcus aureus. Proteins 72(1):229-239

Li B, Yang N, Wang X, Hao Y, Li Z, Mao R (2020) An enhanced variant designed from DLP4 cationic peptide against Staphylococcus aureus CVCC 546. Front Microbiol. https://doi.org/10.3389/ fmicb.2020.01057

Li W, Fu K, Lv X, Wang Y, Wang J, Li H, Tian W, Cao R (2015) Lactoferrin suppresses lipopolysaccharide-induced endometritis in mice via down-regulation of the NF-kappaB pathway. Int Immunopharmacol 28(1):695-699

Liew YK, Awang Hamat R, van Belkum A, Chong PP, Neela V (2015) Comparative exoproteomics and host inflammatory response in Staphylococcus aureus skin and soft tissue infections, bacteremia, and subclinical colonization. Clin Vaccine Immunol 22(5):593-603

Liu Y, Xia X, Xu L, Wang Y (2013) Design of hybrid beta-hairpin peptides with enhanced cell specificity and potent antiinflammatory activity. Biomaterials 34(1):237-250

Noore J, Noore A, Li B (2013) Cationic antimicrobial peptide LL-37 is effective against both extra- and intracellular Staphylococcus aureus. Antimicrob Agents Chemother 57(3):1283-1290

Pietiainen M, Francois P, Hyyrylainen HL, Tangomo M, Sass V, Sahl HG, Schrenzel J, Kontinen VP (2009) Transcriptome analysis of the responses of Staphylococcus aureus to antimicrobial peptides and characterization of the roles of $v r a D E$ and $v r a S R$ in antimicrobial resistance. BMC Genomics 10:429

Pirolo M, Gioffre A, Visaggio D, Gherardi M, Pavia G, Samele P, Ciambrone L, Di Natale R, Spatari G, Casalinuovo F, Visca P (2019) Prevalence, molecular epidemiology, and antimicrobial resistance of methicillin-resistant Staphylococcus aureus from swine in southern Italy. BMC Microbiol 19(1):51

Prokopovich P, Perni S (2009) An investigation of microbial adhesion to natural and synthetic polysaccharide-based films and its relationship with the surface energy components. J Mater Sci Mater Med 20(1): 195-202

Rice KC, Mann EE, Endres JL, Weiss EC, Cassat JE, Smeltzer MS, Bayles KW (2007) The cidA murein hydrolase regulator contributes to DNA release and biofilm development in Staphylococcus aureus. Proc Natl Acad Sci U S A 104(19):8113-8118

Rockel C, Hartung T (2012) Systematic review of membrane components of Gram-positive bacteria responsible as pyrogens for inducing human monocyte/macrophage cytokine release. Front Pharmacol 3:56

Sadykov MR, Bayles KW (2012) The control of death and lysis in staphylococcal biofilms: a coordination of physiological signals. Curr Opin Microbiol 15(2):211-215

Shapiro HM (2000) Membrane potential estimation by flow cytometry. Methods 21(3):271-279

Sheldon IM, Owens SE (2017) Postpartum uterine infection and endometritis in dairy cattle. Anim Reprod 14(3):622-629
Shen F, Tang X, Wang Y, Yang Z, Shi X, Wang C, Zhang Q, An Y, Cheng W, Jin K, Liu M, Guo N, Yu L (2015) Phenotype and expression profile analysis of Staphylococcus aureus biofilms and planktonic cells in response to licochalcone A. Appl Microbiol Biotechnol 99(1):359-373

Skovbakke SL, Franzyk H (2017) Anti-inflammatory properties of antimicrobial peptides and peptidomimetics: LPS and LTA neutralization. In: Hanson PR (ed) Methods in Molecular Biology, 2016/12/26 edn. Springer Natrue, pp 369-386

Speziale P, Pietrocola G, Rindi S, Provenzano M, Provenza G, Di Poto A, Visai L, Arciola CR (2009) Structural and functional role of Staphylococcus aureus surface components recognizing adhesive matrix molecules of the host. Future Microbiol 4(10):1337-1352

Szalus-Jordanow O, Krysztopa-Grzybowska K, Czopowicz M, Moroz A, Mickiewicz M, Lutynska A, Kaba J, Nalbert T, Frymus T (2018) MLST and RAPD molecular analysis of Staphylococcus aureus subsp. anaerobius isolated from goats in Poland. Arch Microbiol 200(9):1407-1410

Tong SY, Davis JS, Eichenberger E, Holland TL, Fowler VG Jr (2015) Staphylococcus aureus infections: epidemiology, pathophysiology, clinical manifestations, and management. Clin Microbiol Rev 28(3): 603-661

Trapnell C, Williams BA, Pertea G, Mortazavi A, Kwan G, van Baren MJ, Salzberg SL, Wold BJ, Pachter L (2010) Transcript assembly and quantification by RNA-Seq reveals unannotated transcripts and isoform switching during cell differentiation. Nat Biotechnol 28(5): $511-515$

Turner ML, Healey GD, Sheldon IM (2012) Immunity and inflammation in the uterus. Reprod Domest Anim 47(Suppl 4):402-409

van der Stel AX, Boogerd FC, Huynh S, Parker CT, van Dijk L, van Putten JPM, Wosten M (2017) Generation of the membrane potential and its impact on the motility, ATP production and growth in Campylobacter jejuni. Mol Microbiol 105(4):637-651

Villanueva M, Jousselin A, Baek KT, Prados J, Andrey DO, Renzoni A, Ingmer H, Frees D, Kelley WL (2016) Rifampin resistance rрoB alleles or multicopy thioredoxin/thioredoxin reductase suppresses the lethality of disruption of the global stress regulator spx in Staphylococcus aureus. J Bacteriol 198(19):2719-2731

Wang L, Feng Z, Wang X, Wang X, Zhang X (2010) DEGseq: an R package for identifying differentially expressed genes from RNAseq data. Bioinformatics 26(1):136-138

Wang X, Teng D, Wang X, Hao Y, Chen H, Mao R, Wang J (2019) Internalization, distribution, and activity of peptide $\mathrm{H} 2$ against the intracellular multidrug-resistant bovine mastitis-causing bacterium Staphylococcus aureus. Sci Rep 9(1):7968

Wang X, Wang X, Teng D, Mao R, Hao Y, Yang N, Li Z, Wang J (2018) Increased intracellular activity of MP1102 and NZ2114 against Staphylococcus aureus in vitro and in vivo. Sci Rep 8(1):4204

Weidenmaier C, Lee JC (2017) Structure and function of surface polysaccharides of Staphylococcus aureus. Curr Top Microbiol Immunol 409:57-93

Wiegand I, Hilpert K, Hancock REW (2008) Agar and broth dilution methods to determine the minimal inhibitory concentration (MIC) of antimicrobial substances. Nat Protoc 3(2):163-175

Wu Y, Li J, Qiao M, Meng D, Meng Q, Qiao J, Zhang X, Wang L, Cai K, Zhang J, Zhang Z, Yu W, Cai X (2019) Characteristic profiles of biofilm, enterotoxins and virulence of Staphylococcus aureus isolates from dairy cows in Xinjiang province, China. J Vet Sci 20(6): e74

Yang S, Lee CW, Kim HJ, Jung HH, Kim JI, Shin SY, Shin SH (2019) Structural analysis and mode of action of BMAP-27, a cathelicidinderived antimicrobial peptide. Peptides 118:170106

Yi H-Y, Chowdhury M, Huang Y-D, Yu X-Q (2014) Insect antimicrobial peptides and their applications. Appl Microbiol Biotechnol 98(13): $5807-5822$ 
Young MD, Wakefield MJ, Smyth GK, Oshlack A (2010) Gene ontology analysis for RNA-seq: accounting for selection bias. Genome Biol 11(2):R14

Yu H, Li N, Zeng X, Liu L, Wang Y, Wang G, Cai S, Huang S, Ding X, Song Q, Qiao S (2019) A comprehensive antimicrobial activity evaluation of the recombinant microcin $\mathrm{J} 25$ against the foodborne pathogens Salmonella and E. coli O157:H7 by using a matrix of conditions. Front Microbiol 10:1954

Zhang XH, Austin B (2005) Haemolysins in Vibrio species. J Appl Microbiol 98(5):1011-1019

Zhang Y, Teng D, Mao R, Wang X, Xi D, Hu X, Wang J (2014) High expression of a plectasin-derived peptide NZ2114 in Pichia pastoris and its pharmacodynamics, postantibiotic and synergy against Staphylococcus aureus. Appl Microbiol Biotechnol 98(2):681-694
Zhang Z, Guo Y, Liu Y, Li C, Guo M, Deng G (2017) IFN-tau displays anti-inflammatory effects on Staphylococcus aureus endometritis via inhibiting the activation of the NF-kappaB and MAPK pathways in mice. Biomed Res Int 2017:2350482

Zharkova MS, Orlov DS, Golubeva OY, Chakchir OB, Eliseev IE, Grinchuk TM, Shamova OV (2019) Application of antimicrobial peptides of the innate immune system in combination with conventional antibiotics-a novel way to combat antibiotic resistance? Front Cell Infect Microbiol 9:128

Publisher's note Springer Nature remains neutral with regard to jurisdictional claims in published maps and institutional affiliations. 